Volume 5 Nomor 1 April 2021

e-ISSN: 2549-9114 dan p-ISSN: 2549-9203

(Received: September-2020; Reviewed: Januari-2021; Published:April-2021)

DOI: https://doi.org/10.26858/pembelajar.v5i1.15142

\title{
Nilai Pembentuk Karakter Anak Dalam Cerita Rakyat Asal-Usul Raja Negeri Jambi
}

\author{
Ahmad Hariandi ${ }^{1}$, Lola Riska ${ }^{2}$, Muhammad Toto Nugroho $^{3}$ \\ ${ }^{123 c}$ Fakultas Keguruan dan Ilmu Pendidikan,Universitas Jambi, Indonesia \\ Corresponding e-mail: ahmad.hariandi@unja.ac.id
}

\begin{abstract}
Abstrak: Cerita rakyat ialah salah satu contoh media yang dapat digunakan sebagai saranamembangun karakter yang positif pada anak sekolah dasar melalui nilai pembentuk karakter yang ada di dalam cerita. Penelitian ini menggunakan jenis penelitian deskriptif kualitatif yang menganalisis nilai pembentuk karakter pada anak dalam cerita rakyat Jambi berjudul Asal-usul Raja Negeri Jambi. Teknik Pengumpulan pada penelitian ini iaklah dilaksanakan dengan membaca teks cerita rakyat Jambi yaitu Asal-usul Negeri Jambi secara berulang-ulang dan menganalisa data berupa kata kunci yang berkaitan dengan nilai-nilai pembentuk karakter dalam cerita tersebut. Selanjutnya data yang telalh dikumpulkan dianalisis dengan menggunakan teknik analisis isi. Hasil penelitian yang diperoleh menunjukkan adanya nilai pembentuk karakter anak dalam cerita rakyat Asalusul Raja Negeri Jambi; yaitu sabar, berani adil dan hemat.
\end{abstract}

Kata Kunci: cerita rakyat, nilai pembentuk karakter, sekolah dasar.

\begin{abstract}
Folktale is one example of media that can be used as a means of building positive character in elementary school children through the character-forming values contained in the story. This study uses a descriptive qualitative research that analyzes the value of character forming in children in Jambi folktale entitled The Origin of the King of Jambi. The collection technique in this study was carried out by reading the text of the Jambi folktale, the Origins of the State of Jambi, repeatedly and analyzing the data in the form of keywords related to the character forming values in the story. Then the data collected was analyzed using content analysis techniques. The results obtained indicate that there is a character forming value for children in the folklore of the Origin of the King of Jami State; namely patience, dare to be fair and thrifty.
\end{abstract}

Keywords: Folktale of Jambi,Values of Character forming, Elementary School.

(C)2021 -Ini adalah artikel dengan akses terbuka dibawahlicenci CC BY-NC-4.0

(https://creativecommons.org/licenses/by-nc/4.0/) by penulis.

\section{PENDAHULUAN}

Cerita rakyat adalah bagian dari tradisi yang muncul dan berkembang di tengah kehidupan rakyat disuatu daerah, dengan menggunakan bahasa sebagai media utamanya, yang terdapat pesan-pesan, cerita-cerita, atau kesaksian-kesaksian sehingga sering juga orang- orang menyebutnya sebagai sastra rakyat. Dalam keseharian cerita rakyat biasanya sampaikan oleh para orang tua kepada anak-anaknya, seorang pendidi yang menyampaikan kepada peserta didik, ataupun antarsesama anggota masyarakat disuatu daerah. Cerita rakyat yang berkembang dalam kehidupan masyarakat di daerah, banyak 
memberikan manfaat dan juga sebuah hiburan yang menyenangkan bagi para pembaca, terkhususnya bagi anak-anaksekolah dasar, hal ini dikarena cerita rakyat dapat menampilkan berbagai kisah yang sangat menarik dan kisah dalam cerita rakyat dapat membuat anak ikut merasakan yang terjadi didalam cerita tersebut, baik ketika suasana dalam cerita bahagia, sedih, tegang serta dapat meningkatkan rasa penasaran anak dengan akhir cerita dalam sebuah cerita rakyat.

Cerita rakyat merupakan cerminan nilainilai yang ada di kehidupan masyarakat. Nilainilai yang terdapat didalam cerita rakyat beredar secara tidak langsung yang kemudian diresapi oleh pembaca, khususnya anak-anak sekolah dasar, secara tidak langsung runtutan dari alur ceritatersebutmampu memengaruhi sikap dan perubahan karakter mereka. Cerita rakyat ialah salah satu sarana untuk menanamkan nilai-nilai dan karakter anak melalui imajinasi mereka dalam mengvisualisasikan alur cerita yang mereka baca. Noor (2011) menyatakan bahwa pada dasarnya cerita rakyat tidak hanya berperan untuk penanaman pondasi keluhuran budi pekerti, tetapi juga memiliki fungsi membentuk karakter individu yang baik sejak dini. Dengan mengajak anak membaca ataupun membacakan cerita rakyat untuk mereka, secara tidak sadar anak-anak bisa bekal pengetahuan tentang berkehidupan di masyarakat.

Cerita rakyat tidak dapat dipisahkan dari dunia anak khususnya di sekolah dasar, hal ini dikarenakan dengan cerita rakyat imajinasi anak dapat terwakilikan sehingga bisa membuat pengetahuan anak berkembang serta dapat menanamkan pendidikan dan karakter yang baik bagi perkembangan anak usia sekolah dasar. Sejalan dengan itu, cerita rakyat tanpa disadari akan menjadi sangat efektif dalam menanamkan pendidikan pada anak, (Kurniawan, 2009: 2). Dengan demikian cerita rakyat sangat bisa dalam membentuk karakter yang positif pada anak secara efektif hal ini karena nilai-nilai karakter yang terkandung di cerita tidak disampaikan secara langsung kepada anak-anak, akan tetapi melalui alur cerita yang dibaca sehingga terjadi suatu proses pendidikan berlangsung secaramenyenangkan dan tidak terkesan menggurui anak-anak.

Sejalan dengan tujuan pendidikan dalam memperkuat pendidikan karakter pada satuan pendidikan yang telah terindentifikasi 18 nilai karakter antara lain religius, jujur, toleransi, disiplin, kerja keras, kreatif, mandiri, demokratis, rasa ingin tahu, semangat kebangsaan, cinta tanah air, menghargai prestasi, bersahabat/komunikatif,cinta damai,peduli lingkungan, gemar membaca, tanggung jawab dan peduli sosial. (Pusat Kurikulum dan Perbukuan, 2011: 8).Melalui cerita rakyat diharapakan dapat menumbuhkan sikap, tingkah laku serta karakter yang baik pada anak sesuai dengan karakter para tokoh dalam cerita. Menurut Wiwin (2016) menyatakan bahwa keseluruhan nilai-nilai dalam gerakan revolusi mental serta pendidikan karakter telah terwujud dan berkembang melalui cerita-cerita rakyat yang tersebar di seluruh daerah, karakter positif yang terdapat dalam cerita rakyat bisa dijadikan sebagai sebuah amanat. Hikmah yang diperoleh pembaca lewat cerita rakyat selalu dalam hal-hal yang baik, akan tetapi karakter buruk pada tokoh dalam cerita rakyat sengaja ditampilkan agar anak-anak tidak mencontoh perilaku buruk tersebut sehingga anak-anak akan termotivasi untuk meniru karakter baik tokoh dalam cerita dikehidupan sehari-hari.

Dalam perkembangan anak usia Sekolah Dasar penanaman karakter melalui media yaitu cerita rakyat memang sangat efektif dikarenakan cerita rakyat sudah terjadi dan masih terbawa dalam suasana kehidupan didaerahnya secara turun-temurun. Sifat anak usia Sekolah Dasar yang masih ingin serba tahu membuat mereka terus mencari tahu dari setiap kejadian yang terjadi didalam cerita rakyat dan membuat secara tidak langsung dapat membentuk karakter yang positif pada anak sekolah dasar. Hidayatullah (2010: 13) Karakter ialah kekuatan mental, moral, budi pekerti serta akhlak yang terdapat didalam individu sebagai kepribadian yang khusus sebagai pendorong, serta membedakan dengan individu lain. Karakter ialah sebuah bentuk tingkah laku yang sesuai dengan budi pekerti dan kaidah moral sehingga membentuk kepribadian khusus seorang individu (Indiarti: 2017). Dengan demikian karakter merupakan tingkah laku atau moral yang dapat membentuk kepribadian yang terdapat didalam diri manusia.

Provinsi Jambi memiliki kekayaan budaya yang sangat beragam salah satunya yaitu cerita rakyat yangberkembang di daerah jambi. Jambi memiliki beragam cerita rakyat seperti putri tangguk, raja jambi penakluk hantu pirau, legenda rang kayo itam, dan juga cerita asal-usul raja negeri jambi. Cerita rakyat tersebut merupakan sebagian dari banyaknya cerita rakyat yang berkembang di Jambi. Oleh karena itu, sangat penting bagi kita untuk berupaya 


\section{Ahmad Hariandi, Lola Riska, Muhammad Toto Nugroho. Nilai Pembentuk Karakter Anak Dalam Cerita Rakyat}

merevitalisasi cerita rakyat jambi dalam bentuk baik dalam penelitian yang berguna dalam menganalisa nilai-nilai pembentuk karakter yang terkandung dalam berbagai cerita rakyat Jambi.

\section{METODE}

Jenis penelitian yang digunakan adalah penelitian kualitatif dengan pendekatan deskriptif. Metode kualitatif digunakan agar mendapatkan data yang mendalam, dari suatu data yang mengandung makna (Ahmad.H, 2016). Sumber data pada penelitian ini yaitu teks cerita rakyat Jambi yang berujudul Asal-usul Raja Negeri Jambi. Teknik pengumpulan data yang digunaka dalam penelitian ini ialah studi pustaka dan pencatatan.

Pengumpulan data dikukan dengan membaca cerita Asal-usul Raja Jambi dengan cermat dan berulang-ulang. Saat melaksanakan membaca teks cerita dengan berulang-ulang dan cermat dilaksanakan pencatatan mengenai nilai pembentuk karakter yang terkandung dalam cerita Asal-usul Raja Negeri Jambi. Instrument dalam penelitian ini ialah peneliti sendiri dengan buku dan alat tulis. Peneliti disini sebagai human instrument yang berfungsi untuk menetapkan fokus dalam penelitian ini, melakukan pengumpulan data yang diperlukan, menganalisis data yang ada, menafsirkan data serta menyimpulkan kesimpulan (Sugiyono, 2012:222).

Teknik analisis data yang digunakan ialah teknik analisis isi. Kemudian hasil analisis data disajikan dengan teknik informal, yaitu sebagai berikut permusan hasil analsisi yang menggunakan kata-kata serta dideskripsikan sedemikian rupa sehingga diperoleh gambaran yang utuh mengeni nilai pembentuk karakter yang tekandung dalam teks cerita Asal-usul Raja Negeri Jambi.

\section{HASIL DAN PEMBAHASAN}

\subsection{Nilai pembentuk Karakter anak dalam cerita rakyat Asal-usul Raja Negeri Jambi}

Berdasarkan hasil penelitian yang dilakukan pada cerita rakyat Asal-usul Raja Negeri Jambi. Tercantum 4 aspek nilai karakter yang ada dalam kutipan dari teks cerita yaitu:

\subsubsection{Nilai sabar}

Nilai sabar tercermin dalam kutipan "karena belum juga berhasil menemukan orang yang sanggup menjalani ujian untuk menjadi
Raja Negeri Jambi, dalam keadaan putus asa mereka bertekad untuk mengarungi samudra di ujung Pulau Sumatra (BCRJ : 2).

Hal ini tercermin dari kegigihan dan kesabaran utusan para pencari raja yang cocok menjadi Raja Negeri Jambi meskipun mereka sudah putus asa tetapi tekad yang kuat mereka rela mengarungi samudra lepas

\subsubsection{Nilai berani}

Nilai berani tercermin dari kutipan teks "Siapa di antara saudara-saudara yang bersedia atau mencalonkan diri menjadi raja?" Kata salah seorang tokoh dari Batin Duo Belas, yang segera disambut oleh tokoh-tokoh masyarakatlain. "Kami dari Tujuh Koto sanggup". "Kami dari Sembilan Koto sanggup." "Kami dari Muaro Sebo dan dari Petajin sanggup. "Apalagi kami dari Batin Duo Belas, pasti sanggup." (BCRJ2:2)

"Mana wakil dari Tujuh Koto? Ayo maju. Kalau takut lebih biak urungkan niat," "Hai, kami dari Tujuh Koto dak kenal kato undur, dak kenak kata menyerah." (BCRJ2:3).

Pada kutipan tersebut setiap perwakilan dari daerah yang mengikuti pesyaratan menjadi Raja Negeri Jambi tampak semangat dan antusias serta memiliki keberanian, keteguhan hati dalam mengikuti setiap tantangan ujian sebagai syarat untuk menjadi raja Jambi

\subsubsection{Nilai hemat}

Nilai hemat tercermin kutipan teks "Penduduk atau rakyat Tujuh Koto, Sembilan Koto, Muara Sebo, Petajin, dan batin Duo Belas segera mempersiapkan perlengkapan seperlunya untuk membangun istana yang bagus."(BCRJ2:6)

Pada kutipan tersebut penduduk menyiapkanperlengkapan membangun istana seperlunya saja karena mereka tidak ingin bermegah-megahan dan berfoya-foya teapi mereka menggunakan hartanya sesuai dengan kebutuhan saja

\subsubsection{Nilai adil}

"Karena manusia makin lama makin pandai berpikir dan kebutuhan hidup juga makin berkembang, sampailah mereka pada pemikiran bahwa hidup harus lebih teratur, harus ada seorang pemimpin yang mampu memimpin desadesa itu, mempersatukan desa-desa itu." (BCRJ2:1)

"Mufakat telah mereka peroleh bahwa siapapun berhak menjadi raja, asalkan telah lulus ujian. Ujiannya antara lain dibakar, direndam dalam air selama tiga hari tiga malam, dan terakhir digiling dengan kilang besi."(BCRJ2:2) 
Pada kutipan (1) dan (2) rakyat Jambi memiliki pemipikir untuk mencari pemimpin untuk mereka. Mereka memperluas pandangan dan melihat persoalan secara objektif masalah dan keadaan yang mereka alami, sehingga mereka ingin memiliki pemimpin yang bisa mengatur hidup merek. Mereka mengadakan ujian yang harus diselasaikan oleh para calon raja Negeri Jambi. Berdasarkan mufakat yang diperoleh siapa saja bisa menjadi raja asalkan berhasil menyelesaikan ujian tersebut, yaitu ujiannya antara lain dibakar, direndam dalam air selama tiga hari tiga malam, dan terakhir digiling dengan kilang besi. adil kepada semua peserta, jika peserta tidak bisa melewati ujian maka dinyatakan gagal menjadi calon raja Jambi.

\section{KESIMPULAN}

Berdasarkan hasil penelitian yang dikemukakan dalam cerita rakyat Asal-usul Raja Negeri Jambi terdapat aspek nilai karakter yaitu sabar, berani, hemat dan adil, nilai-nilai tersebut sangat bermanfaat apabila dapat ditanamkan kepada peserta didik khususnya pada jenjang sekolah dasar. Disarankan untuk peniliti selanjutnya yang akan meniliti nilai karakter yang terdapat dalam cerita asal-usul Raja negeri jambi agar dapat meneliti cerita ini lebih mendalam dengan kajian yang berbeda. Dan diharapkan dengan adanya penilitian ini dapat menarik minat khalayak banyak untuk membaca cerita rakyat jambi dan dapat mengambil nilai karakter yang terdapat dalam cerita rakyar jambi.

\section{DAFTAR PUSTAKA}

Citraningrum, D. M. (2012). Representasi nilai moral masyarakat using dalam cerita rakyat Banyuwangi (Doctoral dissertation, Universitas Negeri Malang).

Erlandini, D. (2011). "Gaya Penceritaan dan Tema Cerita Rakyat Banyuwangi". Skripsi. Universitas Jember. Jember

Hariandi, A., \& Irawan, Y. (2016). Peran Guru dalam Penanaman Nilai Karakter Religius di Lingkungan Sekolah pada Siswa Sekolah Dasar. Jurnal Gentala Pendidikan Dasar, 1(1), 176-189.

Hidayatullah, F. (2010). Pendidikan Karakter: Membangun Peradaban Bangsa. Surakarta: Yuma Pustaka.

Indiarti, W. (2017). Nilai-nilai pembentuk karakter dalam cerita rakyat asal-usul Watu Dodol. Jentera, 6(1), 26-41.
Kaslani. (1997). Cerita Rakyat Dari Jambi 2. Jakarta: PT.Grasindo

Kurikulum, $P$.

Perbukuan.(2011). Panduan

Pelaksanaan Pendidikan Karakter.

Kurniawan, H. (2009). Sastra Anak dalam Kajian Strukturalisme, Sosiologi, Semiotika, hingga Penulisan Kreatif. Yogyakarta: Graha Ilmu,

Noor, R. M. (2011). Pendidikan Karakter Berbasis Sastra: Solusi Pendidikan Moral yang Efektif. Yogyakarta: ArRuzz Media.

Pusat Kurikulum dan Perbukuan. (2011). Panduan Pelaksanaan Pendidikan Karakter. Jakarta: Badan Penelitian dan Pengembangan Kemdiknas.

Sugiyono. (2012). Metode Penelitian Pendidikan. Bandung: Alfabeta 